\title{
Tajwid, Gramatika Bahasa Arab, dan Adaptasi Kebiasan Baru dalam Peribadatan Sehari-Hari
}

\author{
Siti Aminah, Uswatun Hasanah, Imam Wicaksono \\ Fakultas Ilmu Budaya, Universitas Gadjah Mada \\ Korespondensi:aminah_arb@ugm.ac.id
}

\begin{abstract}
The Covid-19 pandemic has brought a new life order which is commonly known as a health protocol implementation. Efforts to deal with the Covid-19 pandemic can be made physically or spiritually. Physical efforts are carried out by applying health protocols in a disciplined manner, while spiritual efforts are carried out by increasing the quality of worship of God. These two efforts must be combined with maintaining the quality of worship in health protocols. In this case, the quality of worship can be improved by deepening the understanding and application of Arabic tajwid and grammar in reciting verse and prayer recitations. In addition, it is necessary to practice morning and evening prayers as self-protection and maintain mental stability. To achieve this goal, this team carried out a community service by compiling two pocketbooks. The first one is related to the application of health protocols in daily worship and another pocketbook containing tajwid material and morning prayer, which was equipped with exposure and training on recitation and reading the morning prayer and evening prayers. These exposures are presented in outreach videos and tutorials. The result shows that people are increasingly aware of implementing health protocols in their daily activities, especially in Islamic worship. In addition, the community's mentality has become more robust, and people have become calmer in living their lives during the pandemic since some people have practiced morning and evening prayers. In addition, they also apply tajwid and Arabic grammar in a better way so that their worship activities become much more solemn.
\end{abstract}

Keywords: persuasive language; outdoor media; behavior change; the Covid-19 pandemic

\begin{abstract}
Abstrak
Pandemi Covid-19 membawa manusia kepada tatanan kehidupan baru dengan menerapkan protokol kesehatan. Upaya untuk mengahadapi pandemi Covid-19 dan agar terhindar dari penularan virus dapat dilakukan secara jasmani ataupum rohani. Upaya jasmaniah dilakukan dengan menerapkan protokol kesehatan secara disiplin, sedangkan upaya rohani dilakukan dengan mendekatkan diri kepada Tuhan dengan meningkatkan kualitas peribadatan. Hal tersebut dapat dilakukan dengan tetap melakukan ibadah dengan menerapkan protokol kesehatan, diikuti dengan pemahaman dan penerapan tajwid dan gramatika Arab dengan benar dalam melafalkan bacaan ayat dan doa. Selain itu, diperlukan pula pengamalan doa pagi dan petang untuk menjaga diri dan meningkatkan kesehatan mental. Untuk mencapai tujuan tersebut, tim melaksanakan pengabdian dengan menyusun buku saku penerapan protokol kesehatan dalam peribadatan sehari-hari dan buku saku yang berisi materi tajwid dan doa pagi-petang yang diikuti dengan penyuluhan dan pelatihan penerapan tajwid dan membaca doa pagi dan petang yang dilakukan dengan membuat video penyuluhan dan tutorial. Hal ini menunjukkan hasil bahwa masyarakat semakin sadar untuk menerapkan protokol kesehatan dalam setiap aktivitas sehari-hari, khususnya dalam peribadatan Islam. Selain itu, mental masyarakat menjadi semakin kuat dan masyarakat menjadi lebih tenang dalam menjalani kehidupan selama pandemi. Hal ini karena sebagian masyarakat telah mengamalkan doa pagi
\end{abstract}


dan petang, serta menerapkan tajwid dan gramatika Arab dengan lebih baik sehingga aktivitas ibadah mereka menjadi semakin khusyuk.

Kata kunci: adaptasi kebiasaan baru; doa pagi dan petang; tajwid

\section{Pendahuluan}

Pandemi Covid-19 membawa dampak perubahan signifikan bagi tatanan kehidupan manusia di seluruh dunia. Pandemi yang dilaporkan pertama kali pada Desember 2019 di Tiongkok ini telah menyebar ke seluruh dunia dengan penambahan kasus baru setiap harinya. Melihat kondisi tersebut, pada 11 Maret 2020, Organisasi Kesehatan Dunia (WHO) mengumumkan status pandemi global (Iskandar dkk., 2020:625). Peningkatan jumlah kasus yang terjadi di Indonesia diikuti oleh berbagai bentuk kebijakan yang di antaranya wacana penerapan adaptasi kebiasaan baru yang mulai digencarkan pemerintah sebagai tahap awal menuju tatanan kehidupan baru dan pembangkitan perekonomian yang terpuruk pada masa pendemi Covid-19. Pemerintah menyerukan agar rakyat Indonesia harus hidup berdamai dengan virus corona (Ihsanuddin, 2020).

Adaptasi kebiasan baru merupakan perubahan perilaku untuk kembali menjalankan kehidupan secara normal, tetapi tetap menerapkan protokol kesehatan untuk mencegah penularan Covid-19. Dengan kata lain, adaptasi kebiasaan baru adalah suatu cara hidup baru atau cara baru dalam menjalankan aktivitas hidup di tengah pandemi Covid-19 yang belum selesai (Habibi, 2020:198). Era ini ditandai dengan fasilitas-fasilitas umum yang mulai beroperasi kembali, seperti pusat perbelanjaan dan bisnis, transportasi umum, sarana pendidikan, termasuk juga tempat ibadah. Untuk itu, masyarakat harus bertransformasi dari peradaban lama ke peradaban baru, misalnya hidup lebih disiplin, menerapkan pola hidup sehat untuk meningkatkan imunitas tubuh, menghindari kerumunan, dan menjaga jarak (physical distancing dan social distancing). Penyikapan yang tidak benar terhadap era adaptasi kebiasaan baru akan berakibat pada meningkatnya penyebaran Covid-19 yang tentu akan berdampak pada menurunnya produktivitas masyarakat dalam berbagai bidang kehidupan.

Untuk itu, penyuluhan untuk mengajak masyarakat agar dapat menyikapi adaptasi kebiasaan baru secara benar sangat diperlukan, khususnya oleh masyarakat yang kurang dapat mengakses berita-berita dan informasi dengan baik. Bukan hanya karena kurangnya sarana informasi, melainkan juga dimungkinkan oleh ketiadaan waktu dan kesempatan untuk mengakses informasi-informasi tersebut kerena kesibukannya mencari penghidupan. Adaptasi kebiasasan baru bukan hanya menuntut perubahan perilaku pada satu bidang kehidupan, tetapi seluruh bidang kehidupan, mulai di dalam rumah bersama keluarga sampai semua aktivitas di luar rumah, termasuk di dalamnya dalam hal pelaksanaan peribadatan sehari-hari. Masyarakat harus memahami bagaimana dan apa yang harus dilakukan agar dapat melakukan semua aktivitasnya termasuk peribadatan sehari-hari secara benar dan aman.

Selain memahami dan menerapkan perubahan, tentunya masyarakat memerlukan adanya penguatan kesehatan mental yang salah satunya dilakukan dengan melakukan peribadatan secara benar dan memperkuat diri dengan doa-doa perlindungan diri dari segala hal yang tidak baik, termasuk paparan virus corona. Doa-doa perlindungan yang 
diajarkan di dalam agama Islam diyakini dapat meningkatkan imunitas tubuh terhadap paparan penyakit, khususnya Covid-19.

Oleh karena peribadatan sehari-hari dalam Islam pada umumnya menggunakan bahasa Arab-seperti salat, berdoa, dan membaca Al-Qur'an-maka penyuluhan menyangkut tajwid dan gramatika dasar bahasa Arab adalah hal yang penting dilakukan karena kesalahan dalam hal tersebut dapat berakibat pada perubahan makna dari bacaan atau doa yang diucapkan. Hal ini didasarkan adanya kenyataan bahwa penerapan tajwid dan gramatika dasar bahasa Arab untuk peribadatan sehari-hari, khususnya bacaan-bacaan salat, doa-doa, dan membaca Al-Qur'an masih kurang sehingga sering kali ditemukan adanya kesalahan dalam tajwid dan kesalahan gramatika sehingga mengubah makna kalimat-kalimat yang dibaca. Pemahaman yang baik terhadap tajwid dan gramatika dasar bahasa Arab, selain menjadikan bacaan salat, doa, dan Al-Qur'an menjadi benar, juga akan meningkatkan kepercayaan diri masyarakat dalam menjalankan ibadahnya yang tentu berkorelasi positif dengan peningkatan imunitas tubuh masyarakat. Dengan demikian, edukasi menyangkut tajwid dan gramatika bahasa Arab bagi masyarakat muslim masih memerlukan dukungan besar, khususnya pihak perguruan tinggi yang di antaranya memiliki kewajiban mempersembahkan pengabdiannya kepada masyarakat luas sehingga masyarakat dapat melakukan peribadatan, khususnya salat, berdoa, dan membaca Al-Qur'an dengan baik dan benar.

Berdasarkan hal tersebut, tim pengabdian Program Studi Sastra Arab FIB UGM melakukan pengabdian kepada masyarakat dengan topik "Tajwid, Gramatika Bahasa Arab, dan Adaptasi Kebiasaan Baru dalam Peribadatan Sehari-Hari: Edukasi Peribadatan Islam bagi Masyarakat Desa Giripurwo, Kecamatan Purwosari, Gunung Kidul”.

\section{Pendekatan Pelaksanaan Program}

Edukasi tentang peribadatan Islam dilaksanakan dalam bentuk penyuluhan dan pembimbingan yang dilakukan secara daring. Topik penyuluhan tersebut adalah urgensi tajwid dan gramatika bahasa Arab dalam peribadatan sehari-hari, seperti salat, berdoa, dan membaca Al-Qur'an, serta bagaimana menjalani kegiatan sehari-hari secara benar dan aman dengan menerapkan protokol kesehatan. Selain itu, dalam rangka penguatan kesehatan mental masyarakat, pengabdian ini juga memberikan dan melatihkan doadoa perlindungan diri dari hal-hal yang tidak baik yang dibaca pada pagi dan siang hari yang dapat pula dibaca setiap kali akan melakukan aktivitas di luar rumah.

Selanjutnya, agar masyarakat mendapatkan pengetahuan dan informasi yang lebih lengkap yang diharapkan dapat juga dimanfaatkan oleh keluarganya atau pihak lain yang tidak dapat bergabung secara langsung pada saat pengabdian dilaksanakan, pengabdian ini dilengkapi pula dengan pengadaan dan pembagian buku saku yang berisi tajwid, kumpulan doa pagi dan sore, serta pedoman penerapan protokol kesehatan dalam peribadatan sehari-hari dan beraktivitas di tempat-tempat umum. Buku saku tersebut dibuat dalam format buku saku dengan desain sederhana yang mudah dipahami oleh masyarakat mitra pengabdian, yaitu masyarakat Desa Giripuwro, Kecamatan Purwosari, Gunung Kidul yang merupakan desa binaan Prodi Sastra Arab.

Kegiatan ini dilaksanakan dalam tiga tahap, yaitu persiapan, pelaksanaan, dan evaluasi. Tahap persiapan dilakukan dengan melakukan survei kebutuhan masyarakat, 
khususnya dalam peribadatan selama pandemi. Survei dilakukan dengan metode wawancara yang dilakukan kepada beberapa tokoh masyarakat. Wawancara dilakukan melalui aplikasi WhatsApp, baik melalui pesan teks maupun panggilan suara. Dari wawancara tersebut diketahui bahwa selama masa adaptasi kebiasaan baru, masyarakat Dukuh Klampok telah melakukan aktivitas seperti biasa, terutama aktivitas peribadatan. Akan tetapi, sebagian masyarakat belum menerapkan protokol kesehatan secara disiplin. Adapun dalam peribadatan sehari-hari, masyarakat Dusun Klampok telah melaksanakan salat berjamaah di masjid, mengadakan pengajian mingguan, tahlilan, dan kegiatan keagamaan lainnya yang berkaitan dengan peristiwa tertentu seperti pernikahan dan peringatan hari besar keagamaan. Kondisi ini memperbesar kemungkinan penyebaran Covid-19 jika protokol kesehatan tidak diterapkan secara disiplin.

Untuk itu, kegiatan dilakukan dengan memberikan pemahaman yang mendalam mengenai pentingnya menerapkan protokol kesehatan secara disiplin dalam setiap aktivitas, terutama peribadatan, dan memberikan pemahaman mengenai peribadatan yang dilakukan secara benar, terutama dalam bacaannya sehingga dapat meningkatkan kesiapan mental masyarakat dalam menghadapi pandemi ini. Penyuluhan difokuskan kepada pentingnya menerapkan tajwid dan gramatika bahasa Arab dasar dalam melafalkan doa-doa peribadatan, baik dalam shalat, membaca Al-Qur'an, maupun doa. Selain itu, untuk meningkatkan kesiapan mental dan kepercayaan diri masyarakat, diberikan pelatihan mengenai bacaan zikir pagi dan petang. Untuk itu, tim melakukan pendampingan bacaan doa pagi-petang yang dilakukan dengan membuat video panduan bacaan sehingga masyarakat dapat mengakses video tersebut sewaktu-waktu mereka akan belajar dan praktik melakukan doa pagi dan petang.

Secara singkat, berikut pendekatan kegiatan yang dilakukan oleh tim.

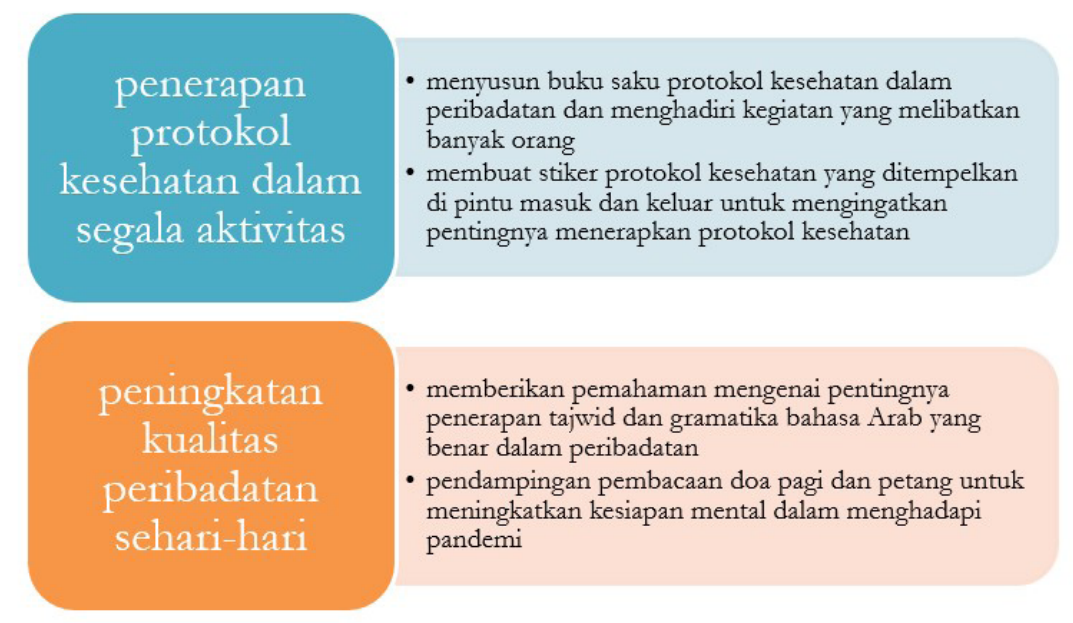

\section{Pelaksanaan Program}

Sebagaimana telah dijelaskan pada bagian sebelumnya, untuk mencapai tujuan tersebut maka kegiatan pengabdian ini dilaksanakan dalam beberapa bentuk kegiatan, yaitu penyusunan buku tajwid dan doa pagi-petang, penyusunan buku panduan adaptasi kebiasaan baru dalam peribadatan sehari-hari, pembuatan video, dan penayangan video dalam pengajian rutin di Masjid Baiturrahim Dusun Klampok. 


\section{Penyusunan Buku Saku Adaptasi Kebiasaan Baru serta Tajwid dan Doa Pagi- Petang}

Untuk memberikan pengetahuan mengenai adaptasi kebiasaan baru, tim menyusun dua buku, yaitu buku adaptasi kebiasaan baru dalam peribadatan sehari-hari dan buku yang berisi materi pengenalan tajwid dan doa pagi-petang. Berdasarkan wawancara yang dilakukan, diketahui bahwa masyarakat Desa Giri purwo telah melaksanakan kegiatan peribadatan secara rutin tetapi belum menerapkan protokol kesehatan secara ketat. Untuk itu, tim menyusun buku panduan adaptasi kebiasaan baru yang berisi panduan-panduan protokol kesehatan yang harus diterapkan dalam aktivitas sehari-hari, terutama aktivitas peribadatan, misalnya protokol kesehatan salat jemaah di masjid, menghadiri pengajian, serta menghadiri kegiatan yang melibatkan banyak orang seperti pemakaman atau pernikahan. Selain itu, buku juga berisi protokol kesehatan ketika mendatangi tempat umum seperti pasar dan sekolah, serta kebiasaan yang harus dilakukan pada saat akan keluar rumah ataupun pulang dari bepergian.

Booklet didesain dengan gambar-gambar ilustrasi yang dilengkapi dengan penjelasan singkat dan jelas sehingga mudah dimengerti, seperti pada gambar 1 .

Tampilan buku saku dibuat dengan warna-warni yang menarik dengan gambar ilustrasi yang dilengkapi dengan teks sederhana. Hal itu dimaksudkan agar masyarakat dapat menangkap pesan yang disampaikan dengan mudah. Selain itu, tampilan buku yang kecil dan ringan diharapkan dapat mudah dibawa ke mana-mana sehingga dapat diakses sewaktu-waktu.

Buku yang kedua (gambar 2) adalah buku yang berisi materi tajwid dan doa pagi dan petang. Materi tajwid disajikan secara singkat dalam bentuk tabel-tabel dengan penjelasan singkat dan contoh yang diambil dari surat-surat pendek dan buku Iqra. Tampilan buku yang demikian diharapkan dapat menarik untuk dibaca dan isinya mudah dimengerti. Materi tajwid meliputi cara membaca nun mati/tanwin dan mim mati ketika bertemu huruf hijaiah, mad, dan tanda waqaf. Hal tersebut menjadi sangat penting untuk disampaikan mengingat kesalahan dalam membaca kata atau kalimat yang mengandung materi di atas berakibat pada perubahan makna sehingga mengurangi kekhusuyukan dalam beribadah.

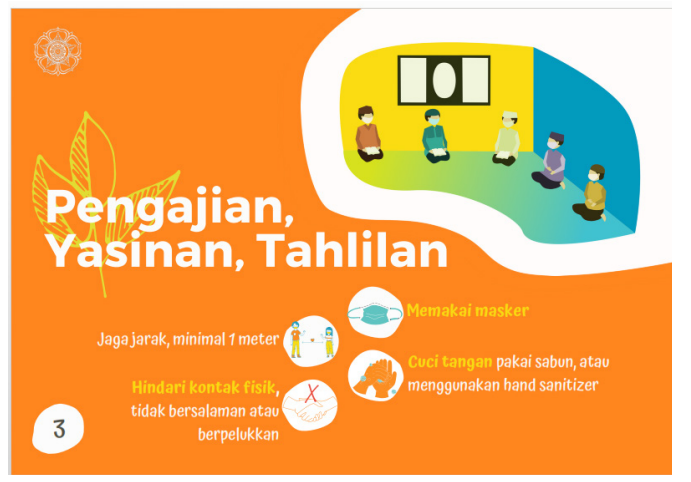

Gambar 1. Contoh tampilan buku saku adaptasi kebiasaan baru dalam menghadiri acara peribadatan

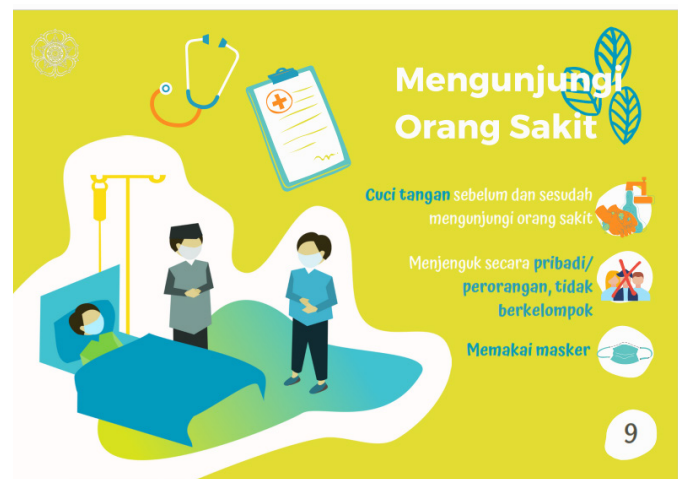

Gambar 2. Contoh tampilan buku saku 


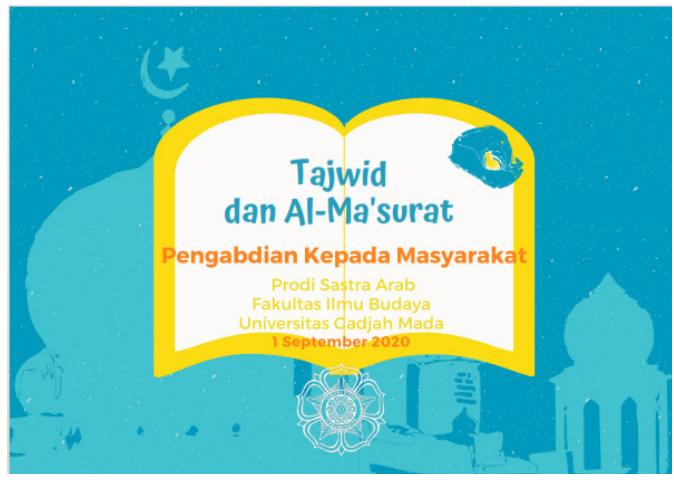

Gambar 3. Sampul buku saku tajwid dan doa pagi dan petang

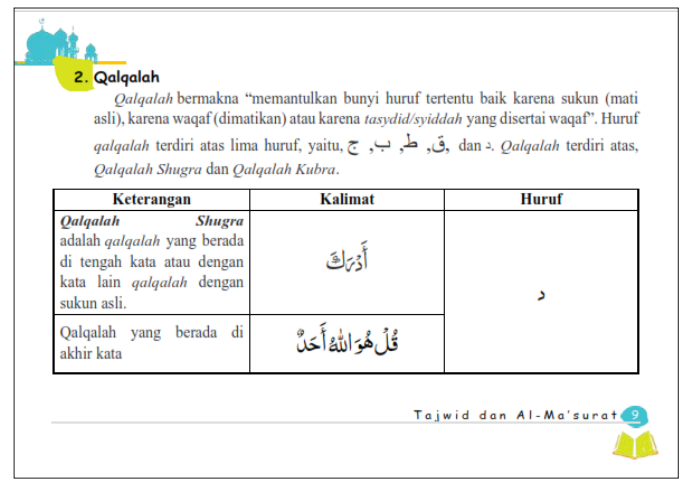

Gambar 4. Tampilan materi tajwid ringkas

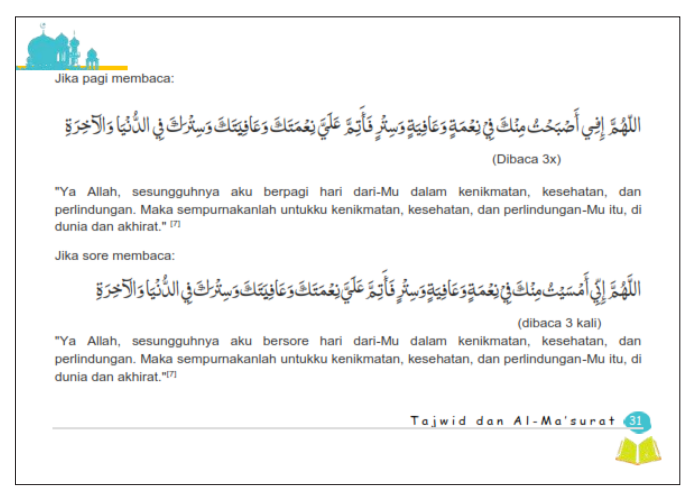

Gambar 5. Tampilan buku doa pagi dan petang

Bagian kedua buku berisi doa pagi dan petang yang dilengkapi dengan arti dan catatan yang berkaitan dengan keutamaan ayat dan doa yang dibaca sehingga masyarakat mengerti arti doa yang mereka baca dan keutamaan doa tersebut. Doa merupakan kutipan dari Al-Ma'surat Hasan al-Banna dengan beberapa penyesuaian. Doa-doa berupa kutipan ayat-ayat Al-Quran, doa pagi dan petang, doa keselamatan, dan beberapa doa lainnya. Setiap kutipan ayat dan doa dilengkapi dengan terjemahannya dalam bahasa Indonesia sehingga masyarakat mengetahui makna doa yang mereka lafalkan. Selain itu, beberapa ayat dan doa diberi catatan yang menunjukkan keutamaan doa atau ayat tersebut sehingga masyarakat menjadi semakin yakin dengan doa yang mereka ucapkan. Untuk membantu masyarakat mengenai cara membaca doa-doa tersebut, tim membuat video bacaan doa-doa dengan intonasi yang jelas dan ritme lambat sehingga bisa diikuti dan ditirukan dengan mudah.

\section{Penyuluban tentang Urgensi Tajwid dan Gramatika Bahasa Arab dalam Peribadatan Sebari-hari}

Setelah buku panduan adaptasi kebiasaan baru dan doa pagi-petang selesai disusun, tim memberikan penyuluhan mengenai urgensi tajwid dan gramatika Arab dalam peribadatan. Pada mulanya, kegiatan ini direncanakan dilaksanakan secara daring melalui platform pertemuan virtual Zoom atau Google Meet. Akan tetapi, setelah dilakukan beberapa kali tes jaringan dan simulasi panggilan video melalui platform pertemuan daring, didapati bahwa di lokasi pengabdian tidak memungkinkan untuk dilaksanakan pertemuan secara sinkronus karena sinyal internet yang lemah. Dengan 
bantuan penduduk setempat, uji coba dilakukan dengan melakukan panggilan video dari kediaman tim pengadian kepada salah satu warga Dusun Klampok. Uji jaringan dilakukan pada hari yang berbeda, dengan waktu yang berbeda pula, yaitu pada sore dan malam hari. Sebenarnya, jaringan pada malam hari lebih kuat dibandingkan pada waktu-waktu lainnya, tetapu belum juga cukup kuat untuk menerima panggilan video atau pertemuan sinkronus.

Agar ceramah dan pendampingan pembacaan doa tetap terlaksana, tim menyusun rencana kedua, yaitu dengan membuat video ceramah dan tutorial membaca doa pagi dan petang. Video tersebut berupa ceramah mengenai urgensi tajwid dan gramatika Arab dalam peribadatan sehari-hari dan dilanjutkan dengan pelajaran tajwid. Konten dalam video tersebut diawali dengan penjelasan mengenai adanya beberapa kesalahan yang umum dilakukan dalam membaca al-Quran dan doa sehari-hari yang mana kesalahan dalam membaca doa dan ayat yang berbahasa Arab dapat mengubah makna doa dan bacaan surat tersebut. Selanjutnya, diberikan pemahaman mengenai urgensi tajwid dan gramatika bahasa Arab dalam peribadatan sehari-hari. Penjelasan dilanjutkan dengan penerapan tajwid dalam peribadatan sehari-hari dengan dihadirkan contoh-contoh bacaan yang sering digunakan dalam peribadatan, misalnya dari surat-surat pendek yang sering digunakan dalam salat.

Penyuluhan tersebut dilakukan pada saat jadwal pengajian rutin, yaitu pada Kamis malam $b a^{\prime} d a$ salat Isya. Kegiatan yang dilakukan di Masjid Baiturrahim tersebut dihadiri oleh jemaah pengajian yang terdiri atas takmir masjid se-Desa Giripurwo dan warga Dusun Klampok. Acara diawali dengan sambutan ketua takmir masjid, kemudian dilanjutkan dengan pemutaran video.
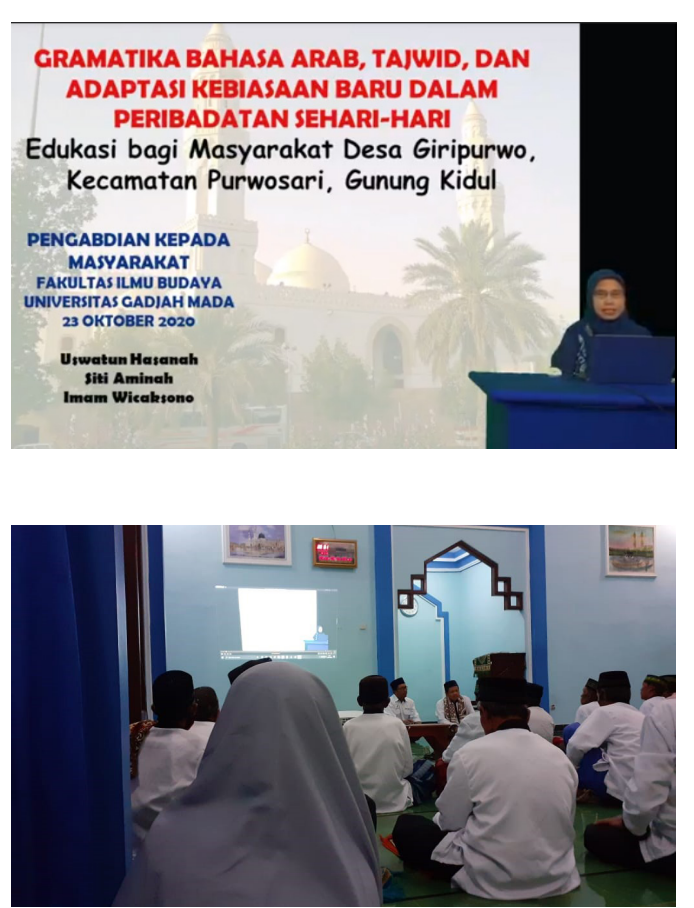

Gambar 7. Warga Dusun Klampok sedang menyimak video mengenai urgensi tajwid dan gramatika Arab
Gambar 6. Tampilan video edukasi mengenai urgensi tajwid dan gramatika Arab dalam peribadatan sehari-hari

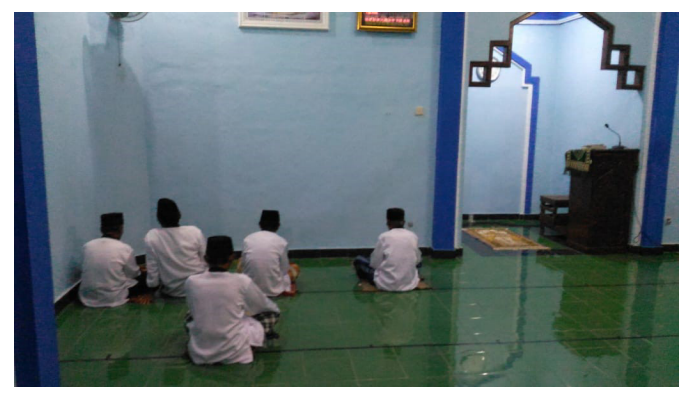

Gambar 8. Warga Dusun Klampok bersiap untuk mengikuti pengajian setelah shalat Isya 


\section{Pendampingan Pembacaan Doa Pagi-Petang}

Karena kendala lemahnya jaringan yang menyebabkan tidak terselenggaranya kegiatan secara sinkronus, pendampingan pembacaan doa pagi-petang juga dibuat dalam bentuk video. Tim yang merupakan dua orang mahasiswa bertindak sebagai pemandu pembacaan doa pagi-petang. Berdasarkan buku saku yang sudah disusun, mahasiswa memandu pembacaan doa pagi dan petang dengan intonasi yang mudah diikuti oleh masyarakat yang belum lancar membaca huruf hijaiyah. Perekaman video dilakukan di studio Fakultas Ilmu Budaya dengan didampingi para petugas IT. Video tersebut kemudian diserahkan kepada salah seorang warga Dusun Klampok untuk kemudian diputar dalam acara pengajian rutin yang dilaksanakan pada Kamis malam.
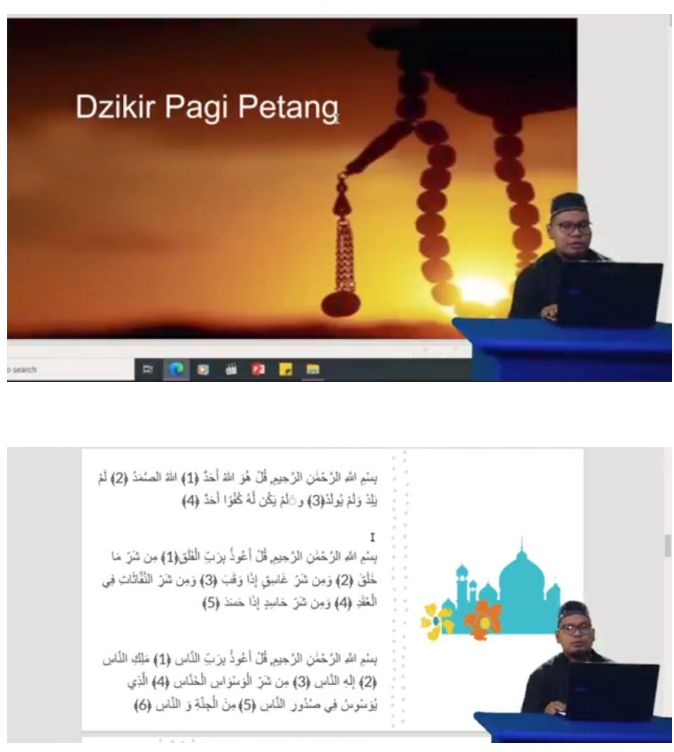

Gambar 10. Tampilan video panduan bacaan zikir pagi dan petang (putra)
Gambar 9. Tampilan awal video panduan bacaan zikir pagi dan petang

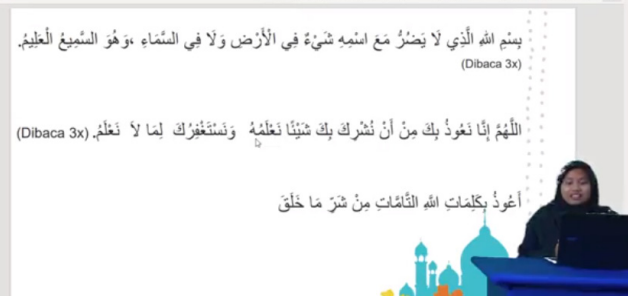

Gambar 11. Tampilan video panduan bacaan zikir pagi dan petang (putri)

\section{Refleksi Capaian Program}

Upaya yang dilakukan oleh tim pengabdian telah menunjukkan hasilnya, yaitu sambutan masyarakat yang begitu antusias dalam mengikuti kegiatan ini. Hal ini terlihat dari banyaknya warga dalam mengikuti pengajian yang dilaksanakan pada Kamis malam langsung setelah salat Isya. Dengan didampingi oleh tokoh agama dan takmir, warga dengan antusias menonton video penjelasan mengenai urgensi tajwid dan gramatika Arab, serta menyimak video panduan bacaan zikir pagi dan petang dengan baik. Kegiatan ini telah menunjukkan keberhasilan sebagai berikut.

\section{Keberhasilan: Masyarakat lebih memahami tajwid dan urgensinya dalam peribadatan sehari-hari}

Penyusunan buku saku yang berisi pelajaran tajwid dasar serta pelaksanaan edukasi yang menekankan pentingnya menerapkan tajwid dan gramatika Arab dengan benar, 
membuat masyarakat menjadi semakin mengerti pentingnya hal tersebut dalam melafalkan doa-doa dalam peribadatan sehari-hari. Masyarakat terlihat telah melafalkan bacaan dalam peribadatan sehari-hari dengan lebih baik dan bisa menerapkan tajwid dan gramatika Arab. Misalnya dalam melafalkan ayat-ayat pendek, masyarakat telah mampu menerapkan perbedaan bacaan izhar dan idgam, membaca mad dengan tepat, serta menerapkan tanda waqaf dengan benar dalam membaca Al-Qur'an.

\section{Masyarakat menjadi lebih siap mental menghadapi pandemi dengan mengamalkan doa pagi dan petang}

Setelah membaca buku doa pagi dan petang dengan mengikuti cara pembacaannya melalui video tutorial yang disusun oleh tim, sebagian masyarakat telah mulai mengamalkan doa pagi dan petang tersebut. Kontinuitas amalan doa pagi dan petang menjadi sangat penting, mengingat doa-doa tersebut merupakan doa perlindungan dari segala macam bahaya termasuk penularan virus Covid-19 sehingga mental masyarakat menjadi semakin kuat dalam menghadapi era adaptasi kebiasaan baru selama pandemi dan seterusnya.

\section{Masyarakat mendapatkan informasi mengenai adaptasi kebiasaan baru dan menerapkannya}

Tujuan penyusunan buku saku mengenai adaptasi kebiasaan baru dalam peribadatan sehari-hari membawa dampak yang positif bagi masyarakat. Masyarakat Desa Giripurwo yang menerima buku tersebut menjadi semakin sadar akan pentingnya menerapkan protokol kesehatan dalam melakukan aktivitas sehari-hari. Hal ini juga didukung dengan adanya penempelan stiker di area pintu keluar-masuk rumah yang berisi peringatan untuk menerapkan protokol kesehatan ketika akan bepergian, misalnya dengan memakai masker ataupun ketika pulang bepergian, seperti mencuci tangan dan membersihkan diri.

Namun, ada beberapa kendala yang dihadapi tim selama pelaksanaan pengabdian. Pertama, dalam tahap persiapan, tim mengalami kendala survei yang kurang maksimal karena tidak dapat terjun langsung ke lokasi pengabdian sehingga informasi awal dan analisis kebutuhan masyarakat tidak didapatkan secara detail. Akan tetapi, cara ini dapat diatasi dengan adanya komunikasi yang intensif antara tim pengabdian dengan masyarakat sehingga informasi yang didapatkan cukup untuk menganalisis kebutuhan dan menentukan pendekatan dalam kegiatan ini.

Pelaksanaan pengabdian yang dilakukan dari rumah masing-masing tentu saja memiliki beberapa keterbatasan karena komunikasi sangat bergantung dari ketersediaan jaringan. Sebagai contoh adalah ketika proses penyusunan buku panduan. Penyusunan buku panduan dapat dilaksanakan dengan baik, tetapi terdapat kendala komunikasi dalam koordinasi tim. Salah seorang mahasiswa memiliki koneksi jaringan yang kurang bagus sehingga sering kali lambat merespons masukan dari tim lainnya yang berakibat pada mundurnya jadwal yang ditetapkan. Kendala komunikasi dan jaringan juga memengaruhi skema jalannya pengabdian yang pada awalnya akan dilaksanakan melalui webinar pada jadwal pengajian rutin Dusun Klampok. Namun, hal ini telah berhasil disiasati dengan melakukuan perekaman video sehingga video tersebut dapat diputar pada acara pengajian rutin sebagai materi pengajian pada hari itu. 


\section{Penutup}

Edukasi peribadatan dalam masa adaptasi kebiasaan baru pada era pandemi Covid19 telah menunjukkan hasil yang positif. Pertama, masyarakat semakin sadar untuk menerapkan protokol kesehatan dalam setiap aktivitas sehari-hari, khususnya dalam peribadatan Islam. Selain itu, masyarakat menjadi semakin kuat dan menjadi lebih tenang dalam menjalani kehidupan selama pandemi. Hal ini karena sebagian masyarakat telah mengamalkan doa pagi dan petang serta menerapkan tajwid dan gramatika Arab dengan lebih baik sehingga aktivitas ibadah mereka menjadi semakin khusyuk.

Sebagai tindak lanjut dari kegiatan ini, ada beberapa kegiatan yang mungkin dapat dilakukan pada masa yang akan datang, di antaranya yaitu pendampingan secara intensif dalam praktik membaca Al-Qur'an dengan tajwid yang benar. Hal ini tentu saja dapat dilakukan baik secara daring melalui video-video pendek mengenai tajwid praktis maupun secara luring dengan terjun langsung ke masyarakat dan melakukan pendampingan secara intensif jika pandemi telah berakhir atau situasi telah memungkinkan. Selain itu, untuk meningkatkan pemahaman terhadap bacaan-bacaan dalam peribadatan sehari-hari, dimungkinkan untuk mengadakan pelatihan bahasa Arab dasar bagi warga dengan mengkaji bacaan-bacaan yang dilafalkan dalam peribadatan. Tujuan kegiatan tersebut adalah membantu masyarakat memahami bacaan yang mereka lafalkan sehingga peribadatan mereka menjadi semakin khusyuk.

\section{Daftar Pustaka}

Habibi, A. (2020). "Normal Baru Pasca Covid-19". ADALAH: Buletin Hukum dan Keadilan Volume 4 Nomor 1. DOI:10.15408/adalah.v4i1.15809.

Ihsanuddin. (2020). "Jokowi sebut hidup berdamai dengan Covid-19, Apa

maksudnya?” dalam https://nasional.kompas.com/read/2020/05/08/06563101/ jokowisebut-hidup-berdamai-dengan-covid-19-apa-maksudnya. Diakses pada 12 Juni 2020.

Iskandar, A. dkk. (2020). "Peran Ekonomi dan Keuangan Sosial Islam dalam Pandemi Covid-19”. SALAM; Jurnal Sosial \& Budaya Syar-i FSH UIN Syarif Hidayatullah Jakarta Vol. 7 No. 7, pp. 625-638, DOI: 10.15408/sjsbs.v7i7.15544.

https://promkes.kemkes.go.id/panduan-pencegahan-penularan-covid-19-untukmasyarakat 